\section{Hawaiian legal action can't save leatherbacks: tackle driftnets instead}

Sir - Your News item" "Researchers take US government to court over threat to turtles" states that the population of Pacific leatherback turtles has declined precipitously, "probably because of their accidental capture by longline fishing". Although Spotila et al., in their Brief Communication in the same issue ${ }^{2}$, document the decline of nesting leatherbacks in Costa Rica, the decline is unlikely to have been caused by the Hawaiian longline fishery.

Nesting populations of leatherbacks on some beaches in the Caribbean and Florida are increasing despite heavy longline fishing in those areas $^{3}$. The turtles that nest in the Eastern Pacific, whose population decline precipitated the news release, have been shown to range primarily off South America ${ }^{4}$, not in the North Pacific area covered by the lawsuit.

Driftnet fisheries off South America have been estimated to kill more than 2,000 leatherback turtles per year ${ }^{5}$. Eckert and Sarti state: "Mortality associated with the swordfish gillnet fisheries in Peru and Chile represents the single largest source of mortality for East Pacific leatherbacks." While longline fishing in the Pacific had spread to cover most of the range of the leatherback by the early 1960s (ref. 6), the precipitous decline in leatherback nesting shown by Spotila et al. ${ }^{2}$ occurred in the late 1980s and early 1990s, when the large-scale high-seas driftnet fishing effort was at its maximum.

Note also that the word "take", as in your reporter's reference to "the unprecedented take of 244 leatherback turtles", refers to any turtle caught on the fishing gear. Most are released alive when the gear is retrieved, so these takes resulted in many fewer deaths.

Your article further reports that "the non-profit law firm works in the area of environmental justice and was looking for plaintiffs to challenge the many unmanaged Hawaiian fisheries". This does not reflect the true state of fisheries management in Hawaii. The Hawaiian longline fishery is under a limited entry-permit system. It has mandatory vessel-tracking system requirements, area closures and mandatory logbooks, and has had a National Marine Fisheries onboard observer programme since 1994.

In fact, the Center for Marine Conservation, the plaintiff in this case, gives a favourable review of fishery management in Hawaii on its website, stating: "The council gets good marks for its regional management efforts". If we wish to save the leatherback turtles of the Eastern Pacific we must correctly identify and deal with the real causes of their decline. This lawsuit is not the solution to the problem.

John LaGrange

Captain, F/V Janthina, 533 North Rios Avenue, Solana Beach, California 92075, USA

\section{Loder, N. Nature 405, 495 (2000).}

Spotila, J. R. et al. Nature 405, 529-30 (2000).

3. Prichard, P. Int. J. Turtle Tortoise Res. 2, 2 (1996).

4. Eckert, S. Hubbs SeaWorld Research Institute Technical Report 99-290 (1999).

5. Eckert, S. \& Sarti, M. Marine Turtle Newsletter 78 1-7 (1997).

6. Suda, A. \& Schaefer, M. B. Bull. I-ATTC 9, 6; 307-462 (1965).

\section{Wise fool left Hussars for career in science admin}

Sir - I was delighted to see Carl Wunsch, in his News and Views item about the Moon and climate, endorsing the most aphoristic of Russian literary heroes, Kozma Prutkov (Nature 405, 743; 2000). However, referring to this 'wise fool' as a private (and adding the impressive Cossack-style drawing) is a mistake.

According to the biography accompanying his works - transcribed by a group of nineteenth-century satirists - he served as a Hussar corporal for three years. All his literary exercises are dated much later in his life, when he was in fact more of a science administrator, working in the State Assay Office responsible for analysing and hallmarking precious metals.

Dmitry Zharkov

Department of Pharmacological Sciences, State University of New York, Stony Brook, New York 11794, USA

\section{Environment regulations hinder biotech industry}

Sir - Your recent Opinion article "Critics of 'gene foods' report are avoiding the real issues" (Nature 404, 689; 2000) neglects several essential points. It referred to a US National Academy of Sciences (NAS) report on a proposed Environmental Protection Agency (EPA) policy, regulating plants manipulated with recombinant DNA for resistance to disease or pests.

The academy's report is flawed, but not in the ways suggested by critics of recombinant DNA technology. It is internally inconsistent and conflicts with previous reports by the academy and other prominent scientific groups. It paves the way for the EPA to introduce an illogical, burdensome scheme that has been repeatedly condemned by the scientific community.

The report's authors ignored the crucial aspects of its brief: "to examine the existing and proposed regulations to qualitatively assess their consequences for research, development, and commercialization of [recombinant plants modified to enhance pest-resistance]"; and to "provide recommendations to address the identified risk/ benefits, and, if warranted, for the existing and proposed regulation of [such plants]".

This point is essential because every other major analysis has found the EPA's regulatory approach to be scientifically insupportable and potentially damaging to agricultural research. In 1987, an academy report concluded that there is no evidence that unique hazards exist either in the use of recombinant DNA techniques or in the movement of genes between unrelated organisms.

In 1989, another NAS study went further, stating that genetic modification by molecular methods creates more predictable results. That report also commented that the method used was not a useful criterion for deciding whether the product needed more supervision.

Nor is it only academy committees that have objected to the EPA approach, which circumscribes only recombinant DNAmanipulated plants for case-by-case review of field trials, and subjects each variety to onerous pesticide-registration procedures. In 1996, a report by 11 scientific societies excoriated the EPA's approach and warned of negative consequences if the EPA's policy were to be implemented. Two years later, the Council on Agricultural Science and Technology (CAST), an international consortium of 36 scientific and professional groups, strongly reiterated these criticisms.

It was extraordinary, therefore, to find in the academy's report that "the committee has chosen to take EPA's proposed rule and the overarching [federal governmental] coordinated framework as given". How could the NAS have gone so far wrong in its assessment of the EPA policy?

The answer is that the committee was 'stacked' - but not in the way alleged by anti-biotechnology critics. Panel members and invited reviewers included well-known ideological opponents to biotechnology and people who had worked on the regulatory approach under discussion while employed at the EPA.

The main consequence of this flawed report will be to promote unwarranted regulatory barriers to the development of much-needed pest-control strategies that can reduce farmers' reliance on chemical pesticides and enhance productivity. If the report is implemented, the costs of research on and commercialization of new plant varieties will be inflated. And it will be another barrier to wide application of costeffective biotechnology to assist agriculture and increase world food production.

Henry I. Miller

Hoover Institution, Stanford University, Stanford, California 94305-6010, USA 